\title{
Influence of the level of development of the digital environment on the trend of gross domestic product in the countries of the European Union
}

\author{
Zaytsev Andrey ${ }^{1 *}$, Konikov Evgeniy ${ }^{1}$, Busheneva Yulia $^{2}$, and Doleva Zarema ${ }^{1}$ \\ ${ }^{1}$ Higher School of Engineering and Economics, Peter the Great Saint Petersburg Polytechnic \\ University, building 29, Polytechnicheskaya street, Saint Petersburg, Russian Federation, 195251. \\ ${ }^{2}$ Pushkin Leningrad State University, Saint Petersburg, building 10, Petersburg highway, Pushkin, \\ Saint Petersburg, Russian Federation, 196605.
}

\begin{abstract}
The paper characterizes the specifics of the impact of digitalization processes on such an indicator as GDP per capita: case study of the European Union countries. The literature dedicated to the matters of the relationship between digitalization and economic growth is reviewed. Based on the statistical data, a regression model is built to determine the dependencies between the GDP of European Union member countries and the economic digitalization indicators. An equation formed in the research can be used to demonstrate the dependence between GDP per capita and the accessibility of information and communications technology and its usage by organizations, households, and private persons in the territory of the European Union. According to the result obtained, the following possible options were formulated for the development of the European Union economies concerning digitalization: stimulating the introduction of information and communications technology in enterprises (including tax incentives for the firms involved in entrepreneurial digital development, as well as growing investments in the existing assets), households (increasing trust of the population in digital products; increasing human capital, which is highly demanded by the digital economy; prospects of the electronic postal trade system); focus on the export of high-tech products.
\end{abstract}

\section{Introduction}

Today, the digitalization of the economy is one of the key trends in the economic systems of many countries. Having an impact on production, distribution, exchange, and consumption, digital transformations make a considerable contribution to GDP and, correspondingly, influence the values of GDP per capita. As a rule, digitalization results in the above indicators' growth due to the increased efficiency of production activities. Digital transformations accelerate such processes as automation and robotization, which are

* Corresponding author: zajtsev.aa@spbstu.ru 
accompanied by an essential update of fixed assets, reduce the share contributed by the labor factor in economic growth, and increase capital contribution practically in all spheres of the economy. In this study, digitalization refers to implementing digital technologies in commercial organizations, state, and public institutions.

Digitalization impacts production growth in all sectors of the economy, but especially on the growth rates of the financial, transport, and construction sector. It also has a positive effect on the efficiency of processing industries. In case the volume of investment is sufficient, digitalization becomes an essential factor of economic growth [1]. Today, digitalization is a priority area for the development of innovation processes in the world's countries as it ensures national and economic competitiveness.

Digitalization plays a unique role in the economic development of the European Union (EU). The European Union is one of the world centers for innovative development and digitalization introduced in the production processes, which has a considerable effect on forming the GDP of the European countries. Digitalization plays a unique role in the economic development of the European Union (EU). The European Union is one of the world centers for innovative development and digitalization introduced in the production processes, which has a considerable effect on forming the GDP of the European countries. The drivers of digitalization in the European Union are strategic programs in this area, a significant amount of funding, and countries' effective innovation policies. The choice of the European Union as the object of research is since this region is one of the leading in the world in the context of digitalization of economic activity.

In 2019, the EU's GDP was estimated at 14 trillion USD [2], which amounts to approximately $22 \%$ of the world GDP. But the contribution of the countries in the formation of GDP is different. The share of the member countries in the formation of the EU GDP is shown in Figure 1.

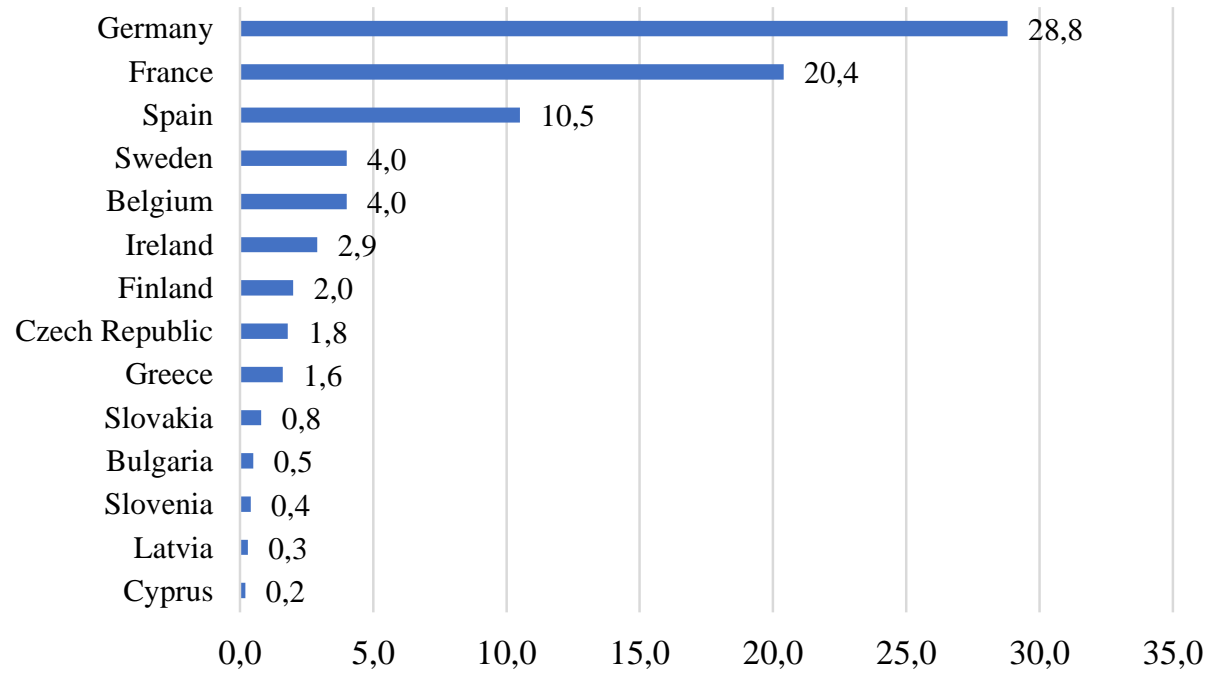

Fig. 1. The share of some EU member countries in the total volume of GDP of the EU, 2019, \%. Author's Analysis, 2020.

The countries of the European Union pay a lot of attention to the development of the digital economy because, in the majority of these countries, they have a strategic understanding of the fact that the future level of economic development of a region depends on how efficiently enterprises are going to use digital technology. In general, we should 
note the growth of GDP per capita in the European Union over the past ten years, which is due, among other things, to active digitalization processes (Figure 2).

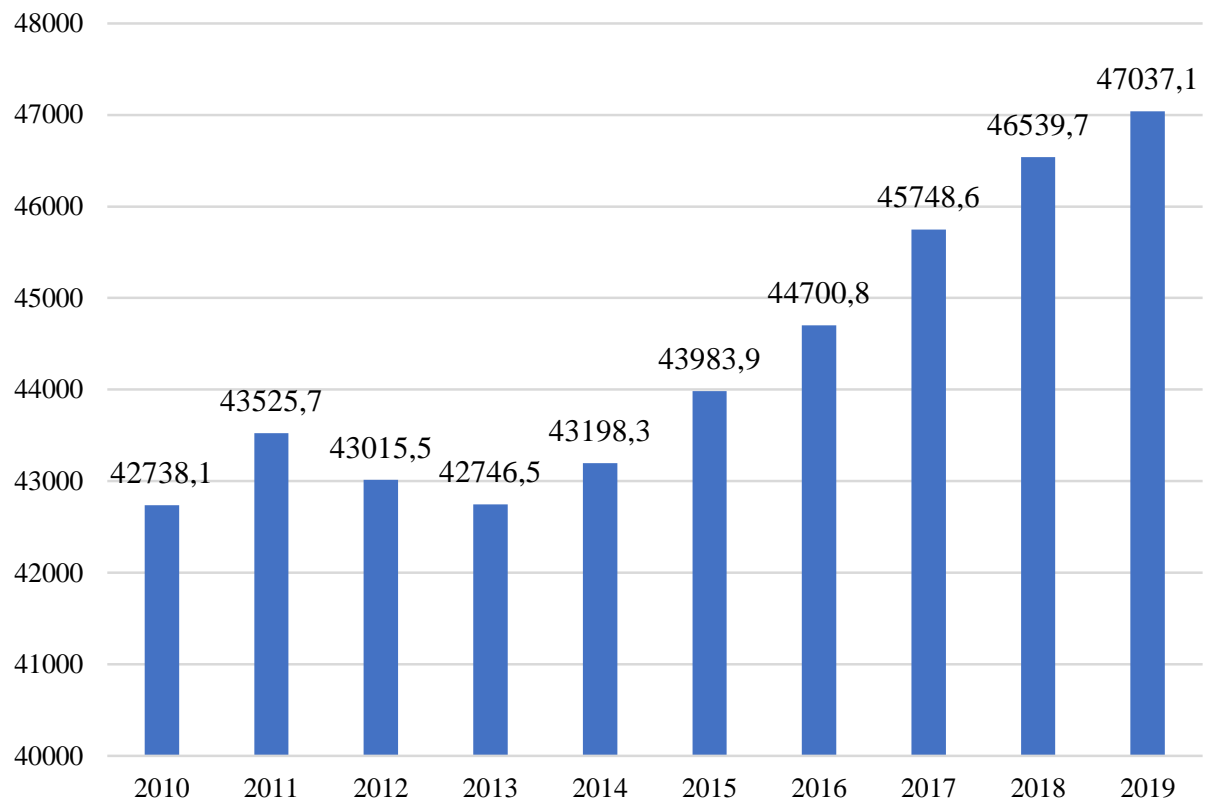

Fig. 2. Dynamics of GDP per capita in the European Union as a whole, USD, World Bank. Author's Analysis, 2020

However, there is a rather big gap in technological development between different EU member countries. According to The Entrepreneurship 2020 Action Plan, the EU countries defined digital transformation as the key driver of economic development.

Despite the significance of the digital economy for economic development, it is worth agreeing with the authors' opinion, who said that no reliable or universal methodology had been created so far to correctly calculate value-added, formed by the digital economic participants' activities [3]. It is an essential restrictive factor for evaluating statistical data and analyzing countries' macroeconomic policy both inside and outside the European Union.

This research aims to study the impact made by the economic digitalization indicators on the country's GDP per capita. To achieve this aim, the following objectives were reached in the course of the research:

1. the list of factors affecting the GDP per capita of the EU countries was defined;

2. methodology was offered for studying the trends in GDP per capita of the EU member countries changing due to economic digitalization;

3. a model showing dependence between the GDP of the EU member countries and economic digitalization indicators was built and, as a result, a multiple regression equation, describing this connection, was formed;

4. recommendations were suggested to improve the interaction between economic entities.

To form the initial list of factors related to digitalization and affect the change in GDP per capita in the EU countries, theoretical sources were reviewed. The specific features of digital technology's effect on economic and social development were analyzed in a whole set of works $[4,5,6,7,8,9,10,11]$. These studies note that the main factor ensuring significant growth of the digital sector of the economy is a growing number of transactions using information channels in all spheres [12]. 
The issues of state policy aimed at supporting digitalization were considered in the works [13], who note that state regulation of the innovation sphere must remain at an insignificant level because in this case a positive effect is formed for investments. Investments are a significant factor in digitalization and its positive influence on GDP. In the authors' opinion, digitalization's positive effect is achieved due to the correction of collapses on the market and the protection of investors' interests.

The matters related to investing in digitalization are considered [15, 16, 17]. It is noted that investing in the sphere of innovative development has a more significant effect on the GPD of the developed countries in comparison to the developing ones. The two-factor analysis carried out by the above researchers shows that investments into technology positively correlate with industry development indicators in certain types of clusters. Simultaneously, it is emphasized that investments into technology can also be destructive and ineffective if procedures aimed at managing the changes are irrational.

The study considers the dependence of economic growth on information infrastructure and investments into venture capital that ensures alternative financing of innovative, hitech, and high-risk firms, which stimulates economic growth and development of highlyinnovative firms [18]. There is a study that highlight the importance of broadband access to the Internet for the digital economy and focus on the impact made by blockchain technology on the growth in production and GDP [19, 20].

In the research, GDP is taken into account as a significant tool for measuring the impact of digitalization. Study the effect of e-commerce and R\&D investments on GDP and productivity, the impact of digitalization on individual aspects of GDP formation [21]. In particular, consumption and distribution are considered in work [22]. However, not all researchers are unanimous in applying GDP as a measurement tool to evaluate the digital economy's efficiency. For instancep, we point out that the development of information technology, as a rule, make prices for this technology grow due to the development of new functional capabilities [23]. Simultaneously, the Internet's promotion reduces prices for the technology because of such characteristics as the provision of information free of charge, easy copying, and mass standardization. In the end, marginal productivity goes down in the leading information companies. To compensate for this reduction, new unique services must be rendered, and even though they are not necessarily recognized in GDP, they measure economic value.

Noted that methodologies for evaluating the effect of digital technology at the macroeconomic level raise a lot of doubts [3]. The data on enterprises operating in the sphere of information technology are used as estimate indicators. However, this sphere is just a means of production for other sectors. This industry is only involved in producing technical means used by firms operating in other sectors for e-banking transactions, ecommerce transactions, etc.

It is also noted that there are some constraints in using GDP for measuring the progress of the digital economy due to the reduction in labor productivity in some industries [9]. These works also highlight the possibilities of accounting for factors that affect GDP in the digital economy [8].

Summarizing this section, it should be mentioned that the above digitalization factors have their specifics and features affecting GDP.

\section{Method}

The classical methodology of regression analysis is used in the research. This methodology implies that the future regression model's endogenous and exogenous variables are defined in the first stage. GDP per capita is the crucial indicator of the country's economic development and standard of living. This indicator is an exogenous or 
dependent variable. Independent variables are investments in venture capital, access to Information and Communications Technology (ICT) and its use by enterprises, access to ICT and its use by households and private persons, the share of individuals using the Internet, the share of individuals having an account, safe internet-servers, postal service trust index, e-commerce index, international trade of ICT services, e-government development index.

The e-government development index is a composite indicator and includes the coverage and quality of online services, the development level of the ICT infrastructure, and human capital. The final set of variables is presented in Table 1.

Table 1. The final set of variables for the regression model establishes dependencies between the EU member countries' GDP and economic digitalization indicators.

\begin{tabular}{|c|c|c|c|c|}
\hline No. & Variable & $\begin{array}{c}\text { Type of } \\
\text { variable }\end{array}$ & Designation & $\begin{array}{c}\text { Measurement } \\
\text { units }\end{array}$ \\
\hline 1. & GDP & $\begin{array}{c}\text { Endogenous } \\
\text { variable }\end{array}$ & $\mathrm{Y}$ & bil. \$ \\
\hline 2. & $\begin{array}{c}\text { Investments in } \\
\text { venture capital }\end{array}$ & $\begin{array}{c}\text { Exogenous } \\
\text { variable }\end{array}$ & $\mathrm{X}_{1}$ & thous. \$ \\
\hline 3. & $\begin{array}{c}\text { Accessibility of ICT } \\
\text { and its use by } \\
\text { enterprises }\end{array}$ & $\begin{array}{c}\text { Exogenous } \\
\text { variable }\end{array}$ & $\mathrm{X}_{2}$ & $\%$ \\
\hline 4. & $\begin{array}{c}\text { Accessibility of ICT } \\
\text { and its use by } \\
\text { households and } \\
\text { private persons }\end{array}$ & $\begin{array}{c}\text { Exogenous } \\
\text { variable }\end{array}$ & $\mathrm{X}_{3}$ & $\%$ \\
\hline 5. & $\begin{array}{c}\text { Share of population } \\
\text { using the Internet }\end{array}$ & $\begin{array}{c}\text { Exogenous } \\
\text { variable }\end{array}$ & $\mathrm{X}_{4}$ & - \\
\hline 7. & $\begin{array}{c}\text { Share of the } \\
\text { population having an } \\
\text { account }\end{array}$ & $\begin{array}{c}\text { Exogenous } \\
\text { variable }\end{array}$ & $\mathrm{X}_{5}$ & $\%$ \\
\hline 8. & $\begin{array}{c}\text { Pafe internet-servers } \\
\text { (standard) }\end{array}$ & $\begin{array}{c}\text { Exogenous } \\
\text { variable }\end{array}$ & $\mathrm{X}_{6}$ & - \\
\hline 9. & $\begin{array}{c}\text { E-commice trust } \\
\text { index }\end{array}$ & $\begin{array}{c}\text { Exogenous } \\
\text { variable }\end{array}$ & $\mathrm{X}_{7}$ & - \\
\hline 10. & $\begin{array}{c}\text { The volume of } \\
\text { international trade of } \\
\text { ICT service }\end{array}$ & $\begin{array}{c}\text { Exogenous } \\
\text { variable } \\
\text { variable }\end{array}$ & $\mathrm{X}_{8}$ & - \\
\hline 11. & $\begin{array}{c}\text { E-government } \\
\text { development index }\end{array}$ & $\begin{array}{c}\text { Exogenous } \\
\text { variable }\end{array}$ & $\mathrm{X}_{10}$ & mil. \$ \\
\hline
\end{tabular}

Regression analysis was chosen for this study, as it allows: (1) to determine the degree of the determinism of differences in the values of the dependent variable in different observations of the independent variable, (2) to predict the values of the dependent variable using the independent variable, (3) to determine the contribution of individual independent variables to variation dependent. The quality of the model is evidenced by several vital analytical indicators:

1. The coefficient of determination $\left(\mathrm{R}^{2}\right)$ is used to assess the linear relationship's quality and reliability, calculated as the squared correlation coefficient. It is assumed that the coefficient of determination should be at least $50 \%$.

2. P-level is an indicator, the value of which reflects the probability of error when the null hypothesis is rejected-defined for each of the independent variables. This figure should not exceed the difference between $100 \%$ and the assumed level of confidence 
in the model results, usually $90 \%, 95 \%$, or $99 \%$. Therefore, the P-level should not exceed $10 \%, 5 \%$, or $1 \%$, respectively.

3. The approximation error is used to assess the quality of the resulting model. The regression model is considered to be effectively formed and fairly reliably describes the relationship between the factor and the significant indicator, if the value of the average approximation error does not exceed 1-10\%, depending on the phenomenon under study.

4. The logical nature of the connection. The direction of the relationship between the variables is determined based on the sign of the regression coefficient. If the regression coefficient sign is positive, the relationship between the dependent variable and the independent variable is considered directly proportional. If the regression coefficient sign is negative, the relationship between the dependent variable and the independent variable is inversely proportional.

5. Lack of structural breaks. Structural gaps should be understood as the multidirectional dynamics of actual $\mathrm{Y}$ and theoretical (calculated using the resulting model) $\mathrm{Y}$.

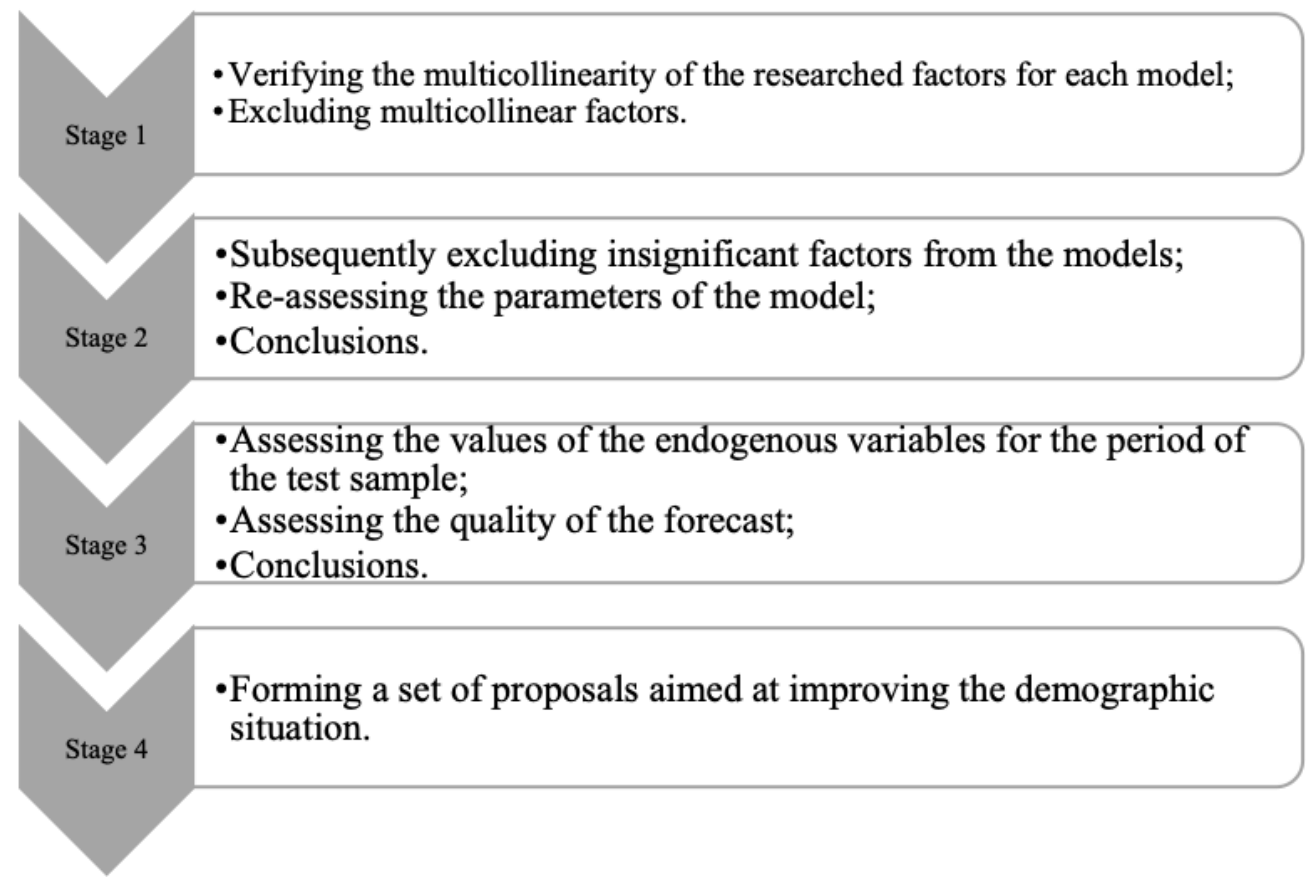

Fig. 3. An algorithm for forming the results of the regression model, establishing the dependencies between the GDP of the EU member countries and economic digitalization indicators.

The algorithm of this research can be represented as follows (Figure 3). The algorithm is automated using specialized software. In this research, the authors used the Microsoft Excel program.

\section{Results and discussion}

\subsection{Main results}

The countries were selected based on open data. In the final research, the indicators of 23 countries were studied. The European Union, as a whole, as well as individual member 
countries, is digitally a well-developed region. This sphere is significantly advanced in such countries as Germany and France. The primary data source was the international statistical agency Eurostat.

It is necessary to define the nature of dependence between the endogenous and exogenous variables at the first stage. The Backwards method was used to select indicators in the model. The criterion for excluding the model's indicators was the p-level, whose boundary value was selected as 0.05 . The authors carried out six iterations and excluded insignificant regressors. The result is a pair regression equation:

$$
\mathrm{Y}_{\text {theor }}=22814 \times \mathrm{e}^{0,0039} \times \mathrm{X}_{7}+925.1 \times \mathrm{e} \times 0.04 \mathrm{X}_{8}+3165.1 \times \mathrm{X}_{9} \times 0.2688
$$

According to this equation, the GDP per capita of the EU member countries depends on the proportion of the population using the Internet and the international trade of ICT services. The determination coefficient is equal to $52 \%$. Figure 4 illustrates the comparative trends in the actual and predicted result.

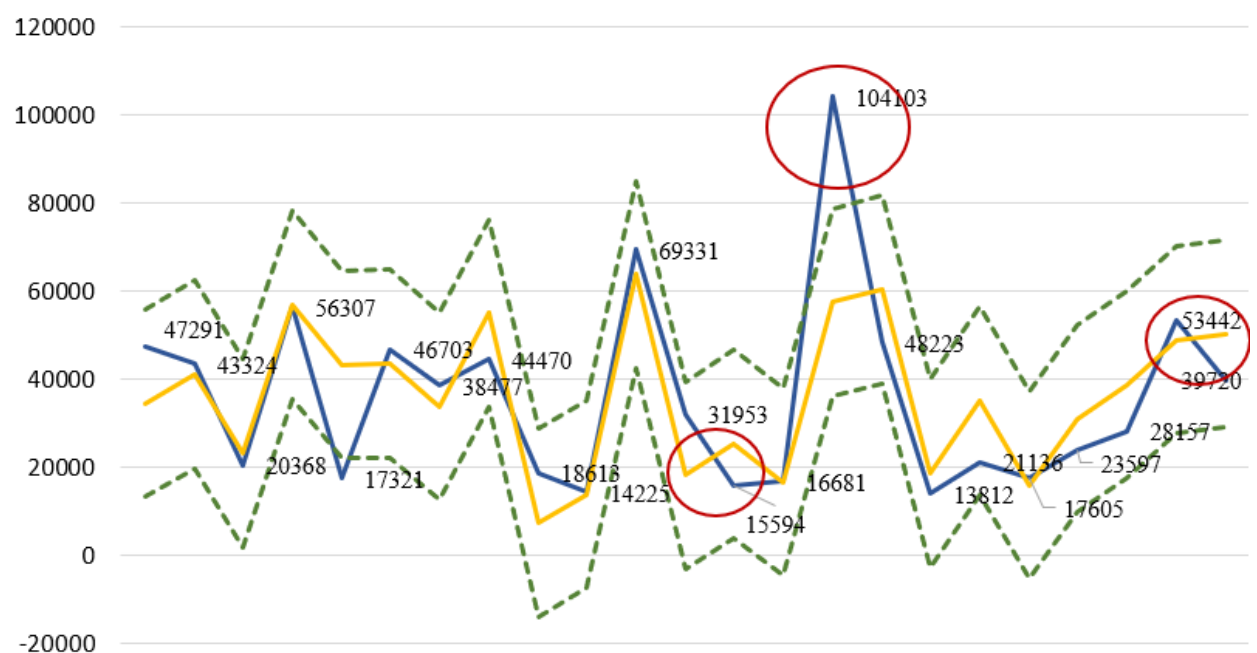

$-20000$

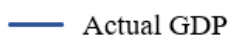

Theoretical GDP

Fig. 4. The trends in the actual and predicted GDP per capita by EU countries. Author's Analysis, 2020

The model has little structural breaks and one structural spike. This indicator belongs to Luxemburg. Luxemburg is a well-developed industrial country, which has the highest GDP per capita in the world, according to the World Bank as of the year 2017.

Having excluded Luxemburg from the sample, the authors obtained the following model:

$$
\begin{array}{r}
\mathrm{Y}=2285.1 \times \mathrm{e}^{0.0325} \times \mathrm{X}_{2}+1357.4 \times \mathrm{X}_{3}-80206+236.37 \times \mathrm{X}_{7}+14353++1258.4 \times \mathrm{X}_{8}- \\
74488+2808.1 \times \mathrm{X}_{9}^{0.2761}
\end{array}
$$

The determination coefficient is equal to $81 \%$. The equation shows the dependence between GDP per capita and accessibility of ICT and its use by enterprises, accessibility of ICT and its use by households and private persons, postal service trust index, e-commerce index, and the volume of international trade of ICT services. Figure 5 illustrates comparative trends in the actual and predicted result according to this model. 


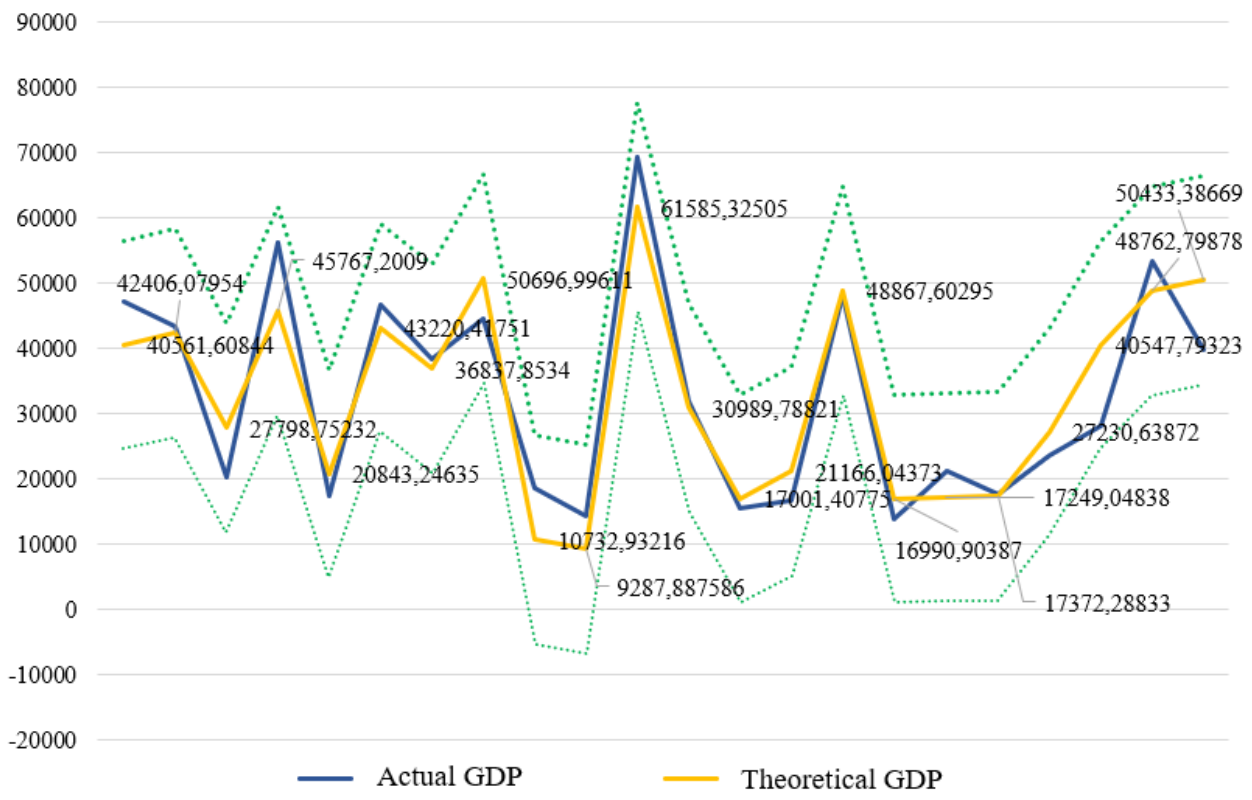

Fig. 5. Trends in the actual and predicted GDP per capita by EU countries EC. Author's Analysis, 2020

As shown in the graph, the predicted values follow the actual ones in a relatively precise way. No spikes are going outside the limits of confidence intervals. Thus, it can be claimed that there is a dependence between GDP per capita and accessibility of ICT and its use by enterprises, accessibility of ICT and its use by households and private persons, postal service trust index, e-commerce index, and the volume of international trade of ICT services. Having performed the analysis, the initial theoretical, conceptual model can be optimized. The final conceptual model is presented in Figure 6.

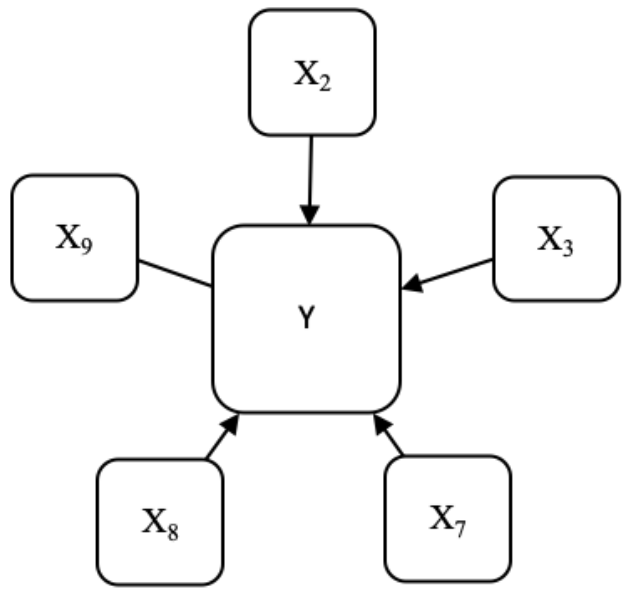

Fig. 6. The verified conceptual model is establishing dependences between the GDP of the EU member countries and economic digitalization indicators. Author's Analysis, 2020

\subsection{Discussion}


The built model allows us to conclude that the digitalization of the economy has a considerable impact on the GDP per capita. The degree of influence of the considered factors is illustrated in Figure 7.

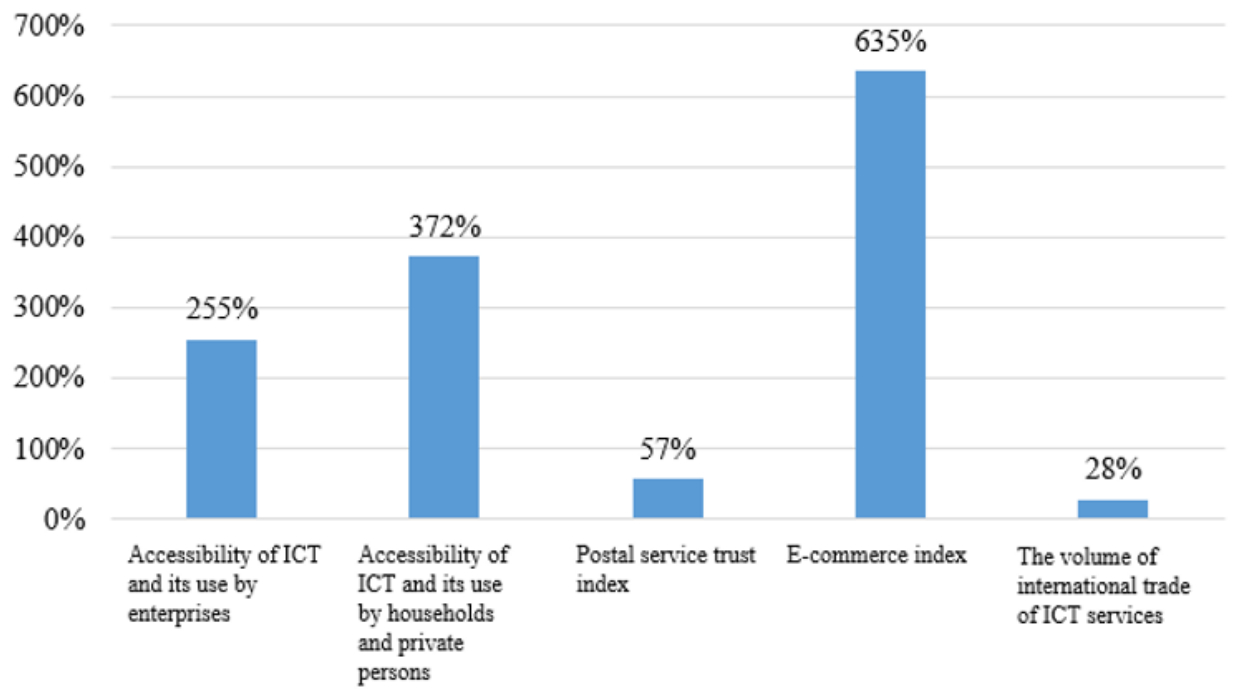

Fig. 7. Elasticity coefficients of the considered factors. Author's Analysis, 2020

The results in Figure 6 demonstrate that the most significant factor of digitalization that affects the growth of GDP per capita is the increase in e-commerce $(635 \%)$, accessibility of information and communications technology and its use by households and private persons (372\%), accessibility of information and communications technology and its use by enterprises $(255 \%)$, what is proved in other studies [7-9, 23]. Thus, the digitalization of the economy is affected by a whole crowd of factors, which are considered, in particular, in work [24]. This research also highlights the digitalizing economy's fundamental technologies as the Internet of Things and Big Data. These technologies are critical because companies with a high digitalization level will have a competitive advantage in the nearest future. The questions of the spread of digital technology and stimuli for its development were considered [25]. The factors revealed in the course of the research, such as accessibility of digital technology and trust in it, which have a significant impact on GDP per capita on an international scale and in terms of individual countries, are considered [26, $27,28,29,30,31]$, which confirms the conclusions made in this paper. The data similar to this research were obtained based on substantiating the digital divide between countries. The impact of this divide on the indicators of GDP and GDP per capita is shown in the works [32].

Together with digitalization, among the factors preconditioning the formation of GDP, the authors also mention education [32], urbanization, and service [34], and entrepreneurship [35]. It is noted that well-thought policy in the field of competition, regulation, protection of intellectual property, and consumer protection can improve the market indicators of the digital economy [36, 37, 38].

The stable growth of the economy and standard of living of the citizens is a top priority for national economies. Today, when information acquires a key resource status, the new paradigm of development is the digital economy. Thus, priority will be given to the following areas of development: 
1 Stimulating further introduction of information and communications technologies in enterprises:

-Tax incentives for the firms involved in advanced $R \& D$;

-Increasing investments in the development of the Internet of Things, Big Data, Cloud Computing;

2 Stimulating further introduction of information and communications technologies in households:

-Building up the trust of the population in internet services and simultaneously increasing the safety of these services;

-Increasing the human capital necessary for the digital economy by improving the literacy of people;

-Developing an accessible and reliable postal system, which is going to be an additional stimulus for people to purchase goods via the Internet, for developing e-commerce;

3 Focusing on the export of hi-tech products;

4 Implementation of technical recommendations for digitalization in the European Union (formation of digital business platforms, state digitalized management systems, state corporations' digital transformation, and companies with state participation).

All these actions aim to digitalize the economy and, correspondingly, at increasing the efficiency of national economies at the present stage of development. As a result of the introduction of the suggested recommendations, the digital divide, created by a different degree of the impact the factors have on the digitalization processes, may be narrowed. However, due to the same factors, there are possibilities for overcoming the existing divide between the countries thanks to the fact that the governments of not only the European Union countries but also other countries intensify their digitalization policy. All these things ensure growth in labor productivity, improve the competitiveness of firms and goods on the external market, reduce production costs, stimulate employment, and better satisfy the needs of the population. If the critical digitalization factors are affected, it may open up a possibility for speeding up the scaling of free digital processes, eventually leading to a growth in GDP as a whole and GDP per capita.

Barriers to digitalization in the European Union are gaps in economic well-being between countries and European integration processes [39], asymmetry in the development of the information society [40].

\section{Conclusion}

Thus, in this research, we assessed the impact made by the digitalization of the economy on the level of economic development and the living standard of this country's population via the relationship with the indicator of GDP per capita. The statistical models we obtained allow us to conclude that the different level of economic digitalization explains GDP trends by country, which is primarily preconditioned by the development of e-commerce. Also, significant variables are GDP, investment in venture capital, the availability of information technologies and their use by businesses, households, individuals, the share of the population using the Internet and having an account, the security of Internet servers, trust in postal services, the volume of international trade in information services, and the development of e-government.

To increase efficiency and competitiveness, it is necessary to improve the level of accessibility of information and communications technology for enterprises, product manufacturers and service providers, private persons and households, consumers of these services and goods.

The applied relevance of the results we obtained implies that they can be used in the practice of state regulation of the economy to identify, assess, and correct the factors that 
impact digitalization processes in well-developed countries. A similar regression model can be formed for developing countries as well, but, in this case, additional factors have to be considered, such as the degree of transparency of economic processes, the reliability of the presented statistics, the degree of economic development of the country. The research perspective can be the study of the prospects and barriers of digitalization, applying the developed regression model to assess the impact of digitalization on the dynamics of changes in GDP per capita in other regions of the world (Asia, America).

\section{Acknowledgements}

This research work was supported by the Academic Excellence Project 5-100 proposed by Peter the Great St. Petersburg Polytechnic University.

\section{References}

1. Y. Stetsunich, Y. Busheneva, A. Zaytsev, Framing public financial policy: transforming the classic concept in the time of digitalization, SPBPU IDE-2019. October 18-19, 2019, Saint - Petersburg, Russia (2019) doi: https://doi.org/10.1145/3372177.3373289

2. International statistics. European Union URL: https://en.tradingeconomics.com/

3. O.M. Mahalina, V.N. Mahalin, Razvitie cifrovoj ekonomiki v global'noj ekonomicheskoj sisteme, Digital economic development in the global economic system, In the collection: Economics and Management in the XXI Century: Development Research Strategies. collection of articles of the III international scientific and practical conference, P.94-98 (2017)

4. N.A. Kulagina, O.V. Mikheenko, D.G. Rodionov, Technologies for the development of methods for evaluating an innovative system, International Journal of Recent Technology and Engineering, 8, 5083-5091 (2019) doi: https://doi.org/10.35940/ijrte.C5714.098319

5. I.A. Rudskaya, D.G. Rodionov, Comprehensive evaluation of Russian regional innovation system performance using a two-stage econometric model, Espacios, 39, 4 (2018)

6. C. Watanabe, K. Naveed, P. Neittaanmäki, Co-evolution of three mega-trends nurtures un-captured GDP - Uber's ride-sharing revolution, Technology in Society, 46, 164185 (2016) https://doi.org/10.1016/j.techsoc.2016.06.004

7. C. Watanabe, K. Naveed, P. Neittaanmäki, Dependency on un-captured GDP as a source of resilience beyond economic value in countries with advanced ICT infrastructure: Similarities and disparities between Finland and Singapore, Technology in Society, 42, 104-122 (2015) https://doi.org/10.1016/j.techsoc.2015.04.003

8. C. Watanabe, K. Naveed, P. Neittaanmäki, Y. Tou, Operationalization of un-captured GDP, Innovation stream under new global mega-trends, Technology in Society, 45, 5877 (2016) https://doi.org/10.1016/j.techsoc.2016.02.008

9. C. Watanabe, K. Naveed, Y. Tou, P. Neittaanmäki, Measuring GDP in the digitaleconomy: Increasing dependence on uncaptured GDP, Technological Forecasting and Social Change, 137, 226-240 (2018) https://doi.org/10.1016/j.techfore.2018.07.053

10. A. Zaytsev, O. Kichigin, A. Korotkova, Standard dynamic financial analysis and control tools of an enterprise in the time of digital economy, SPBPU IDE-2019, October 18-19, 2019, Saint - Petersburg, Russia (2019) 
11. A. Svenfelt, E.C. Alfredsson, K. Bradley, E. Faure, E. Öhlund, Scenarios for sustainable futures beyond GDP growth 2050, FuturesVolume, 111, 1-14 (2019)

12. T.I. Chinaeva, Digital Economy: Development Trends, Russia: Trends and Development Prospects, 6, 24-26 (2017) https://doi.org/10.1016/j.futures.2019.05.001

13. H.-J. Seo, Y.S. Lee, J.H. Oh, Does ICT investment widen the growth gap? Telecommunications Policy, 33, 422-431 (2009) https://doi.org/10.1016/j.telpol.2009.04.001

14. E.A. Gromova, Digital economy development with an emphasis on automotive industry in Russia, Espacios, 40, 6 (2019)

15. E.A. Konnikov, O.A. Konnikova, D.G. Rodionov, Impact of 3D-Printing Technologies on the Transformation of Industrial Production in the Arctic Zone, Resources, 8, 1(2019) doi:10.3390/resources 8010020

16. A. Zaytsev, D. Rodionov, N. Dmitriev, O. Kichigin, Comparative analysis of results on application of methods of intellectual capital valuation. Digital transformation on manufacturing, infrastructure and service, DTMIS 2019, Russia, St. Petersburg (2019)

17. D. Grant, B. Yeo, A global perspective on tech investment, financing, and ICT on manufacturing and service industry performance, International Journal of Information Management, 43, 130-145 (2018) https://doi.org/10.1016/j.ijinfomgt.2018.06.007

18. R.P. Pradhan, M.B. Arvin, M. Nair, S.E. Bennett, S. Bahmani, Short-term and longterm dynamics of venture capital and economic growth in a digital economy: a study of European countries, Journal of Multinational Financial Management, 45, 15-34 (2019) https://doi.org/10.1016/j.techsoc.2018.11.002

19. V.A. Efimushkin, T.V. Ledovskikh, E.N. Scherbakova, Infocommunication Technological Space of the Digital Economy, T-Comm: Telecommunications and Transport, 11, 15-20 (2017)

20. A.V. Babkin, D.D. Burkaltseva, A.V. Betskov, H.S. Kilyaskhanov, A.S. Tyulin, I.V. Kurianova, Automation digitalization blockchain: Trends and implementation problems, International Journal of Engineering and Technology (UAE), 7, 254-260 (2018)

21. R.D. Anvari, D. Norouzi, The Impact of E-commerce and R\&D on Economic Development in Some Selected Countries, Procedia - Social and Behavioral Sciences, 229, 354-362 (2016) https://doi.org/10.1016/j.sbspro.2016.07.146

22. V.G. Minashkin, P.E. Prokhorov, Statistical Analysis of the Use of Digital Technologies in Organizations: A Regional Aspect, Statistics and Economics, 15, 51 $62(2018)$

23. C. Watanabe, Y. Tou, P. Neittaanmäki, A new paradox of the digitaleconomy, Structural sources of the limitation of GDP Technology in Society, 55, 9-23 (2018) https://doi.org/10.1016/j.techsoc.2018.05.004

24. A.A. Kryukova, Yu.A. Mikhalenko, Instruments of the Digital Economy, Karelian Scientific Journal, 3, 108-111 (2017)

25. G. Nicoletti, C. Rueden, D. Andrews, Digital technology diffusion: a matter of capabilities, incentives or both? European Economic Review, 27, 103513 (2020) https://doi.org/10.1016/j.euroecorev.2020.103513

26. L.V. Nikolova, D.G. Rodionov, N.V. Afanasyeva, Impact of globalization on innovation project risks estimation, European Research Studies Journal, 20, 2 (2017)

27. T.V. Verevka, Digital transformation of enterprises of the hospitality industry: Global experience and prospects, Proceedings of the 33rd International Business Information Management Association Conference, 629-640 (2019)

28. G. Myovella, Digitalization and economic growth: A comparative analysis of SubSaharan Africa and OECD, Telecommunications Policy, 44, 2, 2020, Article 101856 (2020) https://doi.org/10.1016/j.telpol.2019.101856 
29. N. Duch-Brown, F. Rossetti, Digital platforms across the European regional energy markets, Energy Policy, 144, 111612 (2020) https://doi.org/10.1016/j.enpol.2020.111612

30. S.U. Lutz, The European digital single market strategy: Local indicators of spatial association 2011-2016, Telecommunications Policy, 43, 393-410 (2019) https://doi.org/10.1016/j.telpol.2018.10.003

31. M.R. Szeles, New insights from a multilevel approach to the regional digital divide in the European Union, Telecommunications Policy, 42, 452-46 (2018) https://doi.org/10.1016/j.telpol.2018.03.007

32. D. Mitrovic, Measuring the efficiency of digital convergence, Economics Letters, 188, 108982 (2020) https://doi.org/10.1016/j.econlet.2020.108982

33. N.C. Jackson, Managing for competency with innovation change in higher education: Examining the pitfalls and pivots of digital transformation, Business Horizons, 62, 761-772 (2019) https://doi.org/10.1016/j.bushor.2019.08.002

34. S. Rok, P. Doo, Y. Choi, P. Hong, Club convergence and factors of digital divide across countries echnological, Forecasting and Social Change, 96, 92-100 (2015)

35. M.A. Galindo-Martin, M.S. Castaño-Martínez, M.T. Méndez-Picazo, Digital transformation, digital dividends and entrepreneurship: A quantitative analysis, Journal of Business Research, 101, 522-527 (2019)

https://doi.org/10.1016/j.jbusres.2018.12.014

36. Y. Chen, Improving market performance in the digital economy, China Economic Review, 62, 101482 (2020)

37. K. Naveed, C. Watanabe, P. Neittaanmäki, The transformative direction of innovation toward an IoT-based society, Increasing dependency on uncaptured GDP in global ICT firms, Technology in Society, 53, 23-46 (2018) https://doi.org/10.1016/j.techsoc.2017.11.003

38. Unctad b2c e-commerce index 2018 focus on africa // https://unctad.org. URL: https://unctad.org/en/PublicationsLibrary/tn_unctad_ict4d12_en.pdf (date of retrieval: 02.06.2020).

39. F. Cruz-Jesus, T. Oliveira, F. Bacao, Digital divide across the European Union, Information \& Management, 49, 278-291 (2012) https://doi.org/10.1016/j.im.2012.09.003

40. M. Rosalia, V. Cuervo, A. Jesus, L. Menendez, L. A multivariate framework for the analysis of the digital divide: Evidence for the European Union-15, L., Information \& Management, 43, 756-766 (2006) https://doi.org/10.1016/j.im.2006.05.001 